УДК 355.402(728)(091)(045)

\title{
3.И. Мамедов
}

\section{МЕЖВЕДОМСТВЕННОЕ ПРОТИВОССТОЯНИЕ В ПРОЦЕССЕ СОЗДАНИЯ ЦРУ}

Данная статья посвящена созданию Центрального разведывательного управления в аспекте межведомственной борьбы. Этот процесс был связан с необходимостью координации всей разведывательной информации, поступавшей в различные государственные органы власти США. Начавшаяся холодная война подталкивала к ускорению формирования нового ведомства. Полномочия, которыми планировалось наделить ЦРУ, не могли возникнуть ниоткуда, поэтому их необходимо было у кого-то забрать и перераспределить. Данный факт обусловил конфликт интересов и межведомственное противостояние за сферы влияния и ресурсы. Исследование проведено на основе официальных меморандумов и деловой переписки. Результаты комплексного источниковедческого анализа позволили идентифицировать основные заинтересованные стороны, их опасения и претензии к новой разведывательной организации. Хронологические рамки исследования — период между заключительным этапом деятельности Управления стратегических служб в 1944 г. и образованием Центрального разведывательного управления в 1947 г.

Ключевые слова: ЦРУ, ФБР, Госдепартамент, Объединённый комитет начальников штабов, США, Группа центральной разведки, холодная война.

DOI: $10.35634 / 2412-9534-2021-31-1-144-151$

Различные аспекты деятельности Центрального разведывательного управления (ЦРУ) рассматривались зарубежными и отечественными авторами многократно. Описывая создание нового ведомства, большинство из них ограничивалось упоминанием о трудности этого процесса, связанного с опасениями появления нового гестапо, общего недовольства конкурирующих ведомств и выработкой потенциальных полномочий. Только в последнее время начали выходить работы, в которых анализировались интересы других ведомств и действия по их защите. В статье М. Ю. Дундукова был проведён анализ установления контрольных полномочий Сената и Палаты представителей в отношении разведывательных служб США, в т. ч. ЦРУ [1, с. 104-120]. С. В. Старкин на основе большой источниковой базы идентифицировал планы президента Трумэна в предстоящей разведывательной реформе. В его работе также были рассмотрены претензии Госдепартамента, который опасался потери части сферы влияния во внешнеполитической аналитике [3, с. 95-108]. Я. А. Левин в ряде статей осветил соперничество Управления стратегических служб (УСС) с ФБР и личное неприятие между Уильямом Донованом и Эдгаром Гувером. Автор подробно представил видение директором ФБР послевоенной разведывательной деятельности [2, с. 106-111]. Таким образом, актуальным направлением является комплексный анализ противостояния всех основных акторов создания ЦРУ.

Первый проект новой разведывательной организации был представлен ещё президенту Рузвельту осенью 1944 г. директором УСС. Понимая, с какими внутренними проблемами столкнётся данная инициатива, Уильям Донован предполагал не затрагивать прерогативы разведывательной деятельности других ведомств, а выполнять функции координирующего центра, подчинённого лично президенту. Даже при том, что по данному проекту ЦРУ не должно было работать на территории США и не имело полицейских функций, весь кабинет министров, кроме президента, высказался отрицательно [32].

После смерти Рузвельта, Донован пытался донести свои идеи до нового президента, но Трумэн вместо этого поблагодарил директора, а УСС расформировал. Из письма президента госсекретарю Джеймсу Бирнсу мы узнаём о том, что он возглавит межведомственную группу по внешней разведке. Таким образом, на первоначальном этапе Госдепартамент вышел в лидеры в противоборстве за ресурсы и наследие УСС [6, p. 331]. Предвидя продолжение давления со стороны военных, Бирнс изложил свой план создания Национального разведывательного управления с административным комитетом, глава которого назначался из Госдепартамента, но при одобрении двух других министерств [8]. Военных данные уступки не устроили, и в своём меморандуме они предложили, чтобы директора ЦРУ назначал президент. Руководитель нового ведомства не имел бы права голоса в консультативном совете и независимого бюджета [19]. Большая часть документов за этот период в действительности циркулировала вокруг интересов военных, которые быстро смогли договориться между собой и продвигали свои инте- 
ресы через Объединённый комитет начальников штабов. Их меморандумы представляли собой новую разведывательную организацию жёстко централизованной и подчинённой военным. Представители ФБР и Госдепартамента допускались до разведывательной деятельности только в мирное время в качестве консультирующих сторон по экономическим и контрразведывательным вопросам [9]. В более позднем меморандуме руководитель разведки военно-морского министерства Сидни Соерс вовсе не допускал присутствия в консультативном совете представителей ФБР. Свою объективность в отстаивании скорректированного проекта Объединённого комитета начальников штабов он усиливал отказом от директорского поста в случае его предложения. Данный факт подтверждает подковёрную игру военноморского министерства и лично Соерса, т. к. он в будущем стал руководителем Группы центральной разведки - промежуточной организацией между УСС и ЦРУ [10, p. 17-19].

В этом ключе очень важна позиция ФБР и лично её директора Эдгара Гувера. Из его деловой переписки становится ясно, что все его планы так или иначе были связаны с усилением собственного ведомства. Разработка проектов новой разведывательной организации в авторстве ФБР становится нам известной из меморандумов для советников директора. Гувер предполагал создание двух разведывательных организаций. При этом первая представляла собой прообраз ЦРУ с внешними функциями в экономической, политической, научной и иных сферах. Вторая организация должна была выполнять контрразведывательные задачи за рубежом, прикрывая деятельность дипломатов в сотрудничестве с военными представителями. Таким образом, директор ФБР стремился, с одной стороны, минимизировать влияние будущего ЦРУ, а с другой - ограничить разведывательную деятельность военных министерств и Госдепартамента [20].

Свои идеи Гувер пытался донести до президента через генерального прокурора Томаса Кларка. Начиная с первого письма, мы видим, что директор ФБР сводил личные счёты с бывшим директором УСС Донованом, выражая сомнения по поводу создания единой разведывательной организации. Гувер предлагал преобразовывать уже имеющиеся основы для разведывательной деятельности в существующих ведомствах без образования должности директора. Аргументами в пользу статус-кво выступали приведённые в письме успешные операции ФБР во время Второй мировой войны в Латинской Америке, отсутствие на этом направлении серьёзных провалов, осведомлённость о тайных операциях СССР и внутри страны, и за рубежом, а также уже действующие юридические положения, регламентирующие разведывательную деятельность. Таким образом, помимо Донована, Гувер вновь стремился ослабить на данном этапе усилившиеся позиции Госдепартамента [15]. Через месяц в следующем письме Кларку директор ФБР попытался нанести удар по военным, говоря, что завершением операций УСС занимается бывший заместитель Донована бригадный генерал Магрудер. Гувер кратко описывает его биографию, намекая на потенциальную военизированность будущей разведывательной организации [16]. В третьем письме он привёл факт о назначении президентом полковника Маккормака руководителем бывших сотрудников УСС в Госдепартаменте. Его перевод из военного звания в гражданский чин, по мнению Гувера, не отменял тот факт, что бывший армейский человек усилит военных, а не дипломатические службы [17]. Помимо письменных попыток не допустить реализации проекта по созданию новой разведывательной организации, по замыслу Донована, ФБР поспособствовало проведению комиссии полковника Ричарда Парка младшего над деятельностью УСС. По результатам были выявлены серьёзные нарушения и ущерб, причинённые американским гражданам, деловым кругам и национальным интересам [30, p. 531]. Проводимая по просьбе Трумэна параллельно независимая комиссия банкира Фердинанда Эмберштадта пришла к выводу о необходимости создания ЦРУ и СНБ, которые смогут координировать всю разведку и консультировать президента по вопросам национальной безопасности. К концу 1946 г. результаты комиссии подтвердили, что данные направления крайне неудовлетворительны [31].

Генеральный прокурор в свою очередь не стал полностью отстаивать интересы ФБР перед президентом. В своём меморандуме Кларк представлял разделение разведывательной деятельности по двум направлениям: аналитическому и оперативному. Первое направление оставалось под руководством Госдепартамента, а второе разделили между собой военное министерство, военно-морское министерство и ФБР по линиям военных, военно-морских и юридических атташе. До политической координации представители ФБР не допускались, ограничиваясь только присутствием в оперативном комитете. Отличным от других проектов было наличие правоохранительных и надзорных полномочий у будущей организации. Таким образом, генеральный прокурор Томас Кларк лишь частично учи- 
тывал интересы ФБР, равно удаляя Госдепартамент и военные министерства, усиливая свою собственную власть [7].

Первый этап борьбы за полномочия и ресурсы закончился в январе 1946 г. Директивой президента, по которой образовывалась Группа центральной разведки (ГЦР) во главе, как говорилось выше, с адмиралом Сидни Соерсом, разведывательные и аналитические функции распределялись между Госдепом и военными министерствами. Новое ведомство не обладало правоохранительными и полицейскими функциями, что можно расценивать как поражение ФБР и Генерального прокурора, которые не были включены в состав Консультативного совета. Не говорилось в директиве и о главенствующей роли Госдепартамента. Поэтому можно говорить о победе на данном этапе военного и военно-морского министерств с перевесом второго, т. к. возглавлять его будут впоследствии два адмирала и один представитель военно-воздушных сил. Не стоит забывать, что ГЦР через директора была подчинена лично президенту, так что можно констатировать усиление личной власти Трумэна [29, p. 89].

Первая директива Соерса на посту ГЦР о включении в Консультативный совет директора ФБР может навести на мысль о том, что это была попытка примириться с обделённым Гувером [4]. Но сомнительная уступка в пользу Гувера была обусловлена слабостью нового ведомства в вопросах денежных и кадровых ресурсов. В действительности Соерс пытался некоторое время продолжить использование сотрудников ФБР за рубежом [11]. Письмо Гувера Кларку подтверждает тот факт, что директор ФБР быстро понял, что для его ведомства никаких выгод это предложенное взаимодействие не сулит. Он отказывается от предоставления помощи, мотивируя необходимостью высококвалифицированных кадров внутри страны и опасениями насчёт вербовки своего персонала сотрудниками ГЦР [18]. Тем временем на прерогативы ФБР продолжался нажим. Представители разведки военноморского министерства настаивали на возможности налаживания контактов с гражданами США, которые выезжали за рубеж, внутри страны [21]. В июле 1946 г. ГЦР директивно забирало в свои полномочия контрразведывательные полномочия за границей США [26]. Таким образом, ФБР потерпело окончательное поражение в сложившейся борьбе за разведывательные полномочия, а дальнейшее взаимодействие с ГЦР, как и впоследствии с ЦРУ, продолжится только по официальным запросам и периодическому допуску ведомства к секретной информации.

С образованием Группы центральной разведки не прекратились трения с Государственным департаментом по вопросу координации, оценивания и стратегирования внешнеполитических дел. На заседании Национального разведывательного управления была достигнута договорённость, по которой директор ГРЦ будет лишь доносить до президента фактическую разведывательную информацию без оценок и предложений. В свою очередь госсекретарь заверил директора в том, что сотрудники других ведомств будут подчинены только ему [22]. В июне 1946 г. Соерса сменил генерал Хойт Ванденберг - начальник разведки Генерального штаба. Таким образом, военные ещё раз укрепили своё положение, продвинув своего человека [12]. Победу военных над Госдепартаментом подтверждает тот факт, что выбор производился исключительно из военных и утверждался президентом и военным министром. Из последнего меморандума Соерса в качестве директора ГЦР мы видим, что в количественном отношении сотрудников в новом ведомстве из ВМ и ВМС в несколько раз больше, чем из Госдепартамента. Косвенным доказательством ослабления внешнеполитического министерства может являться формирование в ГЦР отдела фотографической и биографической разработки на основании архива Госдепартамента [13, p. 41-45]. Решающий удар по Бирнсу Ванденберг нанёс начавшимися ежедневными и еженедельными разведывательными отчётами для президента, которые сопровождались разъяснительными приложениями. Новый директор ГЦР, несмотря на заверения Соерса, стал интерпретировать мировое положение и давать различные рекомендации. Так, Госдепартаменту пришлось поделиться своими исключительными полномочиями [23].

На последнем этапе создания ЦРУ стала нарастать конфронтация с военными из-за финансовых обязательств, которые легли на ВМ США [27], и из-за недостаточного предоставления армейских кадров в ведомство ГЦР [24]. Военные министерства саботировали предложения по ряду совместных разведывательных операций, мотивируя отказ уже проводящимися работами по тому или иному направлению [25]. Ванденбергу пришлось пойти на компромисс по вопросу атомной разведки. Разведывательная информация по этому направлению должна была предоставляться созданной Комиссии по атомной энергетике от всех разведывательных служб по отдельности, но координация перешла в полномочия директора ГЦР [14]. 
В декабре 1946 г. в Конгрессе США прошли слушания по вопросам организации сбора, оценки и распространения разведывательной информации, затрагивающей военные возможности США. В ходе заседания были сформулированы новые стратегические подходы и видение американским руководством роли, сущности и места разведки в современном мире. Трагические последствия японской атаки на Пёрл-Харбор и немецкого наступления в Арденах объяснялись не отсутствием разведывательной информации, а пренебрежением ею со стороны военных. Эти формулировки были завершением организационного этапа создания централизованной гражданской координирующей разведки США, которой будет суждено стать независимой от остальных правительственных ведомств. Новому ведомству ещё оставалось оформиться в качестве юридического лица для того, чтобы можно было оформлять договоры и вести полноценную разведывательную деятельность [5, p. 188].

Это не означало, что создание ЦРУ было решённым вопросом. Президент Трумэн проводил Закон о национальной безопасности, в совокупности реорганизуя военные министерства, создавая Совет национальной безопасности и ЦРУ. Несмотря на то, что вопросы разведки специально выставлялись в качестве второстепенных аспектов, в Конгрессе основные нападки были именно на них. Эмоциональные нарекания новой организации в качестве американского гестапо перекликались с претензиями относительно концентрации большой власти в руках директора Национальной разведки. Опасения вызывали включение руководителя разведки в СНБ, возможность назначения на этот пост военного и таким образом подчинения разведки министерству обороны. Негодование вызывала расплывчатая формулировка о возможности президента ставить перед ЦРУ дополнительные задачи, которые, как позже покажет практика, будут реализовываться в качестве тайных операций. Продолжали требовать уступки и некоторые правительственные ведомства. В результате на них пришлось пойти. За соглашение о координирующей роли ЦРУ в области разведки военным было разрешено проводить разведывательную деятельность в любых её проявлениях. Интересы Госдепартамента в совокупности с военными были учтены в возможности наличия собственных отделов разведки. ФБР смогло полностью оставить за собой функции разведки и контрразведки внутри страны, предоставляя ЦРУ и СНБ лишь ту информацию, которая будет затрагивать интересы национальной безопасности. Проблема персонификации ЦРУ была решена возможностью назначения на пост директора и из военного, и из гражданского персонала [32 р. 22-25].

Образование ЦРУ 18 сентября 1947 г. было частью объективного процесса модернизации оборонной и разведывательной системы США, обусловленного сложившимися реалиями и на международной арене, и в системе государственного управления. ЦРУ становилось независимой разведывательной организацией, не обладающей полицейскими, судебными, надзорными и правоохранительными функциями под контролем СНБ. Межведомственное противостояние в рамках этого процесса не прошло бесследно, оно выразилось в ряде уступок и корректировок, проанализированных и приведённых в данном исследовании. Личные интересы, в конечном итоге, уступили место общим целям, заключавшимся в закреплении статуса США как главного противника в холодной войне против сложившегося социалистического блока. Страна нуждалась в центральном органе, осуществляющем сбор и анализ разведывательной информации и координирующем подрывную деятельность за рубежом. Закон о национальной безопасности установил фундамент разведывательной деятельности более чем на полвека вперёд - до 2004 г. На наш взгляд, в рамках исследуемой темы перспективным является комплексный анализ проблематики отстаивания и партийных интересов, и интересов отдельных конгрессменов в процессе создания ЦРУ.

\section{СПИСОК ИСТОЧНИКОВ И ЛИТЕРАТУРЫ}

1. Дундуков М. Ю. Развитие контрольных полномочий Конгресса в отношении разведывательных служб // Вестн. Моск. ун-та. Сер.: Право. 2014. № 1. С. 104-120.

2. Левин Я. А. Колониальная система после 1945 г. в оценках ЦРУ // Вестн. Волгогр. гос. ун-та. Сер. 4: История. Регионоведение. Международные отношения. Т. 21, № 4. 2018. С. 95-108.

3. Старкин С. В. Проблемы генезиса американского разведывательного сообщества после Второй мировой войны // Вестн. Челяб. гос. ун-та. 2011. № 22. С. 106-111.

4. Central Intelligence Group Directive No. 1, Washington, February 19, 1946, National Archives and Records Administration, RG 218, Records of the Joint Chiefs of Staff, Leahy Papers. № 130. Top Secret. URL: https://history.state.gov/historicaldocuments/frus1945-50Intel/d104

5. House Report № 2734, 79 Congress 17.12.1946 Committee on Military Affairs. Special Committee. "National security act of 1947". Hearings before the Committee on expenditures in the executive department 80-th Congr. I sess. 
June 2, 1947. Washington: Governmental Printing Office 1982. URL: https://legcounsel.house.gov/Comps/National $\% 20$ Security $\% 20$ Act $\% 20$ Of $\% 201947$

6. Letter From President Truman to Secretary of State Byrnes, Washington, September 20, 1945, Public Papers of the Presidents of the United States: Harry S. Truman, 1945. URL: https://history.state.gov/

7. Memorandum From Attorney General Clark to President Truman, National Archives and Records Administration, RG 51, Records of the Office of Management and Budget, Director's Files, Series 39.27, Intelligence Secret. URL: https://history.state.gov/historicaldocuments/frus1945-50Intel/d19

8. Memorandum From Secretary of State Byrnes to Secretary of War Patterson and Secretary of the Navy Forrestal, Washington, Truman Library, Papers of Clark M. Clifford, National Intelligence Authority, December 10, 1945. URL: https://history.state.gov/historicaldocuments/frus1945-50Intel/ch1?start=31

9. Memorandum From the Chief of Naval Operations and Commander in Chief, U.S. Fleet (King) to Secretary of the Navy Forrestal, Washington, October 9, 1945, National Archives and Records Administration, RG 80, General Records of the Department of the Navy, Sec Nav/CNO Top Secret Correspondence File, 1945, Box 21, Folder A8. URL: https://history.state.gov/historicaldocuments/frus1945-50Intel/ch1?start=31

10. Memorandum From the Deputy Director of Naval Intelligence (Souers) to Clark M. Clifford, Washington, December 27, 1945, Truman Library, Papers of Clark M. Clifford, National Military Establishment: CIA. Top Secret; Personal. Also reproduced in CIA Cold War Records: The CIA under Harry Truman. URL: https://history.state.gov/historicaldocuments/frus1945-50Intel/ch1?start=31

11. Memorandum From the Director of Central Intelligence (Souers) to President Truman, Washington, April 17, 1946, Central Intelligence Agency Historical Files, HS/CSG-2227, Job 83-00739R, Box 2, Folder 3. URL: https://history.state.gov/historicaldocuments/frus1945-50Intel/ch1?start=31

12. Memorandum From the Director of Central Intelligence (Souers) to the President's Chief of Staff, Washington, May 7 , 1946, Truman Library, Papers of Harry S. Truman, President's Secretary's Files. Secret. URL: https://history.state.gov/ historicaldocuments/frus1945-50Intel/ch1?start=31

13. Memorandum From the Director of Central Intelligence (Souers) to the National Intelligence Authority, Washington, June 7, 1946, Central Intelligence Agency Historical Files, HS/HC-39, Item 1. Top Secret. Also reproduced with title page in CIA Cold War Records: The CIA under Harry Truman. URL: https:/history.state.gov/ historicaldocuments/frus1945-50Intel/ch1?start=31

14. Memorandum From the Director of Central Intelligence (Vandenberg) to the National Intelligence Authority, Washington, August 13, 1946, National Archives and Records Administration, RG 59, Records of the Department of State, Decimal File 1945-49, 101.5/8-1546. URL: https://history.state.gov/

15. Memorandum From the Director of the Federal Bureau of Investigation (Hoover) to Attorney General Clark, Washington, August 29, 1945, National Archives and Records Administration, RG 263, Records of the Central Intelligence Agency, Troy Papers, FBI Documents. URL: https://history.state.gov/

16. Memorandum From the Director of the Federal Bureau of Investigation (Hoover) to Attorney General Clark, Washington, September 6, 1945, National Archives and Records Administration, RG 263, Records of the Central Intelligence Agency, Troy Papers, FBI Documents. URL: https://history.state.gov/

17. Memorandum From the Director of the Federal Bureau of Investigation (Hoover) to Attorney General Clark, Washington, September 27, 1945, National Archives and Records Administration, RG 263, Records of the Central Intelligence Agency, Troy Papers, FBI Documents. URL: https://history.state.gov/

18. 18 Memorandum From the Director of the Federal Bureau of Investigation (Hoover) to Attorney General Clark, Washington, August 8, 1946, National Archives and Records Administration, RG 263, Records of the Central Intelligence Agency, Troy Papers, FBI Documents, Box 8, Folder 18. URL: https://history.state.gov/

19. Memorandum From the Secretary of State's Special Assistant for Research and Intelligence (McCormack) to Secretary of State Byrnes, Washington, January 7, 1946, National Archives and Records Administration, RG 59, Records of the Department of State, Decimal File 1945-49, 101.5/1-746. URL: https://history.state.gov/historicaldocuments/ frus1945-50Intel/ch1?start=31

20. Memorandum From Arnold Miles of the Bureau of the Budget Staff to the Assistant Director for Administrative Management of the Bureau of the Budget (Stone), Washington, September 19, 1945, National Archives and Records Administration, RG 51, Records of the Office of Management and Budget, Director's File, Series 39.27, Intelligence. URL: https://history.state.gov/historicaldocuments/frus1945-50Intel/ch1?start=31

21. Minutes of the Fifth Meeting of the Intelligence Advisory Board, Washington, June 10, 1946, 2:30 p.m., Central Intelligence Agency Historical Files, HS/HC-281. URL: https://history.state.gov/

22. Minutes of the First Meeting of the National Intelligence Authority, Washington, February 5, 1946, 11:30 a.m., National Archives and Records Administration, RG 59, Records of the Department of State, Decimal File 1945-49, 811.002/1-2446. URL: https://history.state.gov/

23. Minutes of the Seventh Meeting of the Intelligence Advisory Board, Washington, August 26, 1946, 2:30 p.m., Central Intelligence Agency Historical Files, HS/HC-281. URL: https://history.state.gov/ 
24. Minutes of the Seventh Meeting of the National Intelligence Authority, Washington, September 25, 1946, 11:15 a.m., National Archives and Records Administration, RG 218, Records of the Joint Chiefs of Staff, Leahy Papers, No. 132. URL: https://history.state.gov/

25. Minutes of the Tenth Meeting of the Intelligence Advisory Board, Washington, November 7, 1946, 2:30 p.m., Central Intelligence Agency Historical Files, HS/HC-281. URL: https://history.state.gov/

26. National Intelligence Authority Directive No. 5, Washington, July 8, 1946, National Archives and Records Administration, RG 218, Records of the Joint Chiefs of Staff, Leahy Papers, No. 132. URL: https://history.state.gov/

27. National Intelligence Directive No. 4, Washington, April 2, 1946, National Archives and Records Administration, RG 218, Records of the Joint Chiefs of Staff, Leahy Papers, No. 132. URL: https://history.state.gov/

28. National Security Act of 1947, Hearing before the Committee on Expenditures. 80th Congress. I sess. on H.R. 2319, June 27, 1947. Washington: Governmental Printing Office. 1982. URL: https://history.state.gov/

29. Presidential Directive on Coordination of Foreign Intelligence Activities, Washington, January 22, 1946, Public Papers of the Presidents of the United States: Harry S. Truman, 1946. URL: https://history.state.gov/

30. Thomas F. Troy, Donovan and the CIA: A History of the Establishment of the Central Intelligence Agency, Featured Story Archive CIA 1981. URL: https://www.cia.gov/library/publications/intelligence-history/oss/art02.htm

31. Unification of the War and Navy departments and postwar organization for national security: report to Hon. James Forrestal, Secretary of the Navy. U.S. Senate Committee on Naval Affairs, 79th Cong., 1st sess., Oct. 22, 1945. Washington, G.P.O., 1945. URL: https://history.state.gov/

32. William J. Donovan, Memorandum for the President, Studies Archive Indexes, CIA, November 18, 1944. URL: https://www.cia.gov/library/center-for-the-study-of-intelligence/kent-csi/vol3no3/html/v03i3a07p_0001.htm

Поступила в редакцию 25.02.2020

Мамедов Заур Ималверди оглы, аспирант кафедры всеобщей истории, методики обучения и права ФГБОУ ВО «Самарский государственный социально-политический университет» 443099, Россия, г. Самара, ул. Максима Горького, 65

E-mail: mamedov.zaur.1993@gmail.com

DOI: 10.35634/2412-9534-2021-31-1-144-151

\title{
Z.I. Mamedov
}

INTERDEPARTMENTAL CONFRONTATION IN THE CIA CREATION

\author{
DOI: $10.35634 / 2412-9534-2021-31-1-144-151$
}

This article is devoted to the creation of the Central Intelligence Agency in the aspect of interagency struggle. This process was associated with the need to coordinate all intelligence information received by various US government agencies. The outbreak of the Cold War pushed to accelerate the formation of a new department. The powers that the CIA planned to give could not arise out of nowhere, so they had to be taken from someone and redistributed. This fact caused a conflict of interest and interagency confrontation over spheres of influence and resources. The study was conducted on the basis of official memoranda and business correspondence. The results of a comprehensive source analysis allowed us to identify the main stakeholders, their concerns and claims for the new intelligence organization. The chronological framework of the study was concluded between the final stage of the Strategic Services Directorate in 1944 and the formation of the Central Intelligence Directorate in 1947.

Keywords: CIA, FBI, State Department, Joint Chiefs of Staff, United States, Central Intelligence Unit, Cold War.

\section{REFERENCES}

1. Dundukov M. Yu. Razvitie kontrol'nyh polnomochij Kongressa v otnoshenii razvedyvatel'nyh sluzhb [Developing Congressional Control over Intelligence Services]. Vestnik Moskovskogo Universiteta, seriya Pravo [Bulletin of Moscow University, series Pravo], 2014, no. 1, pp. 104-120. (In Russian).

2. Levin Ya. A. Kolonial'naya sistema posle $1945 \mathrm{~g}$. v ocenkax CzRU [Colonial system after 1945 as assessed by the CIA]. Vestnik Volgogradskogo gosudarstvennogo universiteta, Seriya 4, Istoriya. Regionovedenie. Mezhdunarodnye otnosheniya [Bulletin of Volgograd State University, Series 4, History. Regional studies. International relationships], 2018, vol. 21, no. 4, pp. 95-108. (In Russian).

3. Starkin $S$. $V$. Problemy genezisa amerikanskogo razvedyvatel'nogo soobshhestva posle Vtoroj mirovoj vojny [Problems of the genesis of the American intelligence community after World War II]. Vestnik Chelyabinskogo gosudarstvennogo universiteta [Bulletin of Chelyabinsk State University], 2011, no. 22, pp. 106-111. (In Russian). 
4. Central Intelligence Group Directive No. 1, Washington, February 19, 1946, National Archives and Records Administration, RG 218, Records of the Joint Chiefs of Staff, Leahy Papers, No. 130. Top Secret. URL: https://history.state.gov/historicaldocuments/frus1945-50Intel/d104

5. House Report N 2734, 79 Congress 17.12.1946 Committee on Military Affairs. Special Committee. «National security act of $1947 »$ ». Hearings before the Committee on expenditures in the executive department 80-th Congr. I sess. June 2, 1947. Washington: Governmental Printing Office 1982. URL: https://legcounsel.house.gov/Comps/National $\%$ 20Security\%20Act $\% 20$ Of $\% 201947$

6. Letter From President Truman to Secretary of State Byrnes, Washington, September 20, 1945, Public Papers of the Presidents of the United States: Harry S. Truman, 1945. URL: https://history.state.gov/

7. Memorandum From Attorney General Clark to President Truman, National Archives and Records Administration, RG 51, Records of the Office of Management and Budget, Director's Files, Series 39.27, Intelligence. Secret. URL: https://history.state.gov/historicaldocuments/frus1945-50Intel/d19

8. Memorandum From Secretary of State Byrnes to Secretary of War Patterson and Secretary of the Navy Forrestal, Washington, Truman Library, Papers of Clark M. Clifford, National Intelligence Authority, December $10,1945$. URL: https://history.state.gov/historicaldocuments/frus1945-50Intel/ch1?start=31

9. Memorandum From the Chief of Naval Operations and Commander in Chief, U.S. Fleet (King) to Secretary of the Navy Forrestal, Washington, October 9, 1945, National Archives and Records Administration, RG 80, General Records of the Department of the Navy, Sec Nav/CNO Top Secret Correspondence File, 1945, Box 21, Folder A8. URL: https://history.state.gov/historicaldocuments/frus1945-50Intel/ch1?start=31

10. Memorandum From the Deputy Director of Naval Intelligence (Souers) to Clark M. Clifford, Washington, December 27, 1945, Truman Library, Papers of Clark M. Clifford, National Military Establishment: CIA. Top Secret; Personal. Also reproduced in CIA Cold War Records: The CIA under Harry Truman. URL: https://history.state.gov/historicaldocuments/frus1945-50Intel/ch1?start=31

11. Memorandum From the Director of Central Intelligence (Souers) to President Truman, Washington, April 17, 1946, Central Intelligence Agency Historical Files, HS/CSG-2227, Job 83-00739R, Box 2, Folder 3. URL: https://history.state.gov/historicaldocuments/frus1945-50Intel/ch1?start=31

12. Memorandum From the Director of Central Intelligence (Souers) to the President's Chief of Staff, Washington, May 7, 1946, Truman Library, Papers of Harry S. Truman, President's Secretary's Files. Secret. URL: https://history.state.gov/historicaldocuments/frus1945-50Intel/ch1?start=31

13. Memorandum From the Director of Central Intelligence (Souers) to the National Intelligence Authority, Washington, June 7, 1946, Central Intelligence Agency Historical Files, HS/HC-39, Item 1. Top Secret. Also reproduced with title page in CIA Cold War Records: The CIA under Harry Truman. URL: https://history.state.gov/historicaldocuments/frus1945-50Intel/ch1?start=31

14. Memorandum From the Director of Central Intelligence (Vandenberg) to the National Intelligence Authority, Washington, August 13, 1946, National Archives and Records Administration, RG 59, Records of the Department of State, Decimal File 1945-49, 101.5/8-1546. URL: https://history.state.gov/

15. Memorandum From the Director of the Federal Bureau of Investigation (Hoover) to Attorney General Clark, Washington, August 29, 1945, National Archives and Records Administration, RG 263, Records of the Central Intelligence Agency, Troy Papers, FBI Documents. URL: https://history.state.gov/

16. Memorandum From the Director of the Federal Bureau of Investigation (Hoover) to Attorney General Clark, Washington, September 6, 1945, National Archives and Records Administration, RG 263, Records of the Central Intelligence Agency, Troy Papers, FBI Documents. URL: https://history.state.gov/

17. Memorandum From the Director of the Federal Bureau of Investigation (Hoover) to Attorney General Clark, Washington, September 27, 1945, National Archives and Records Administration, RG 263, Records of the Central Intelligence Agency, Troy Papers, FBI Documents. URL: https://history.state.gov/

18. Memorandum From the Director of the Federal Bureau of Investigation (Hoover) to Attorney General Clark, Washington, August 8, 1946, National Archives and Records Administration, RG 263, Records of the Central Intelligence Agency, Troy Papers, FBI Documents, Box 8, Folder 18. URL: https://history.state.gov/

19. Memorandum From the Secretary of State's Special Assistant for Research and Intelligence (McCormack) to Secretary of State Byrnes, Washington, January 7, 1946, National Archives and Records Administration, RG 59, Records of the Department of State, Decimal File 1945-49, 101.5/1-746. URL: https://history.state.gov/historicaldocuments/ frus 1945-50Intel/ch1?start $=31$

20. Memorandum From Arnold Miles of the Bureau of the Budget Staff to the Assistant Director for Administrative Management of the Bureau of the Budget (Stone), Washington, September 19, 1945, National Archives and Records Administration, RG 51, Records of the Office of Management and Budget, Director's File, Series 39.27, Intelligence. URL: https://history.state.gov/historicaldocuments/frus1945-50Intel/ch1?start=31

21. Minutes of the Fifth Meeting of the Intelligence Advisory Board, Washington, June 10, 1946, 2:30 p.m., Central Intelligence Agency Historical Files, HS/HC-281. URL: https://history.state.gov/ 
22. Minutes of the First Meeting of the National Intelligence Authority, Washington, February 5, 1946, 11:30 a.m., National Archives and Records Administration, RG 59, Records of the Department of State, Decimal File 1945-49, 811.002/1-2446. URL: https://history.state.gov/

23. Minutes of the Seventh Meeting of the Intelligence Advisory Board, Washington, August 26, 1946, 2:30 p.m., Central Intelligence Agency Historical Files, HS/HC-281. URL: https://history.state.gov/

24. Minutes of the Seventh Meeting of the National Intelligence Authority, Washington, September 25, 1946, 11:15 a.m., National Archives and Records Administration, RG 218, Records of the Joint Chiefs of Staff, Leahy Papers, No. 132. URL: https://history.state.gov/

25. Minutes of the Tenth Meeting of the Intelligence Advisory Board, Washington, November 7, 1946, 2:30 p.m., Central Intelligence Agency Historical Files, HS/HC-281. URL: https://history.state.gov/

26. National Intelligence Authority Directive No. 5, Washington, July 8, 1946, National Archives and Records Administration, RG 218, Records of the Joint Chiefs of Staff, Leahy Papers, No. 132. URL: https:/history.state.gov/

27. National Intelligence Directive No. 4, Washington, April 2, 1946, National Archives and Records Administration, RG 218, Records of the Joint Chiefs of Staff, Leahy Papers, No. 132. URL: https://history.state.gov/

28. National Security Act of 1947, Hearing before the Committee on Expenditures. 80th Congress. I sess. on H.R. 2319, June 27, 1947. Washington: Governmental Printing Office. 1982. URL: https://history.state.gov/

29. Presidential Directive on Coordination of Foreign Intelligence Activities, Washington, January 22, 1946, Public Papers of the Presidents of the United States: Harry S. Truman, 1946. URL: https://history.state.gov/

30. Thomas F. Troy, Donovan and the CIA: A History of the Establishment of the Central Intelligence Agency, Featured Story Archive CIA 1981. URL: https://www.cia.gov/library/publications/intelligence-history/oss/art02.htm

31. Unification of the War and Navy departments and postwar organization for national security: report to Hon. James Forrestal, Secretary of the Navy. U.S. Senate Committee on Naval Affairs, 79th Cong., 1st sess., Oct. 22 , 1945. Washington, G.P.O., 1945. URL: https://history.state.gov/

32. William J. Donovan, Memorandum for the President, Studies Archive Indexes, CIA, November 18, 1944. URL: https://www.cia.gov/library/center-for-the-study-of-intelligence/kent-csi/vol3no3/html/v03i3a07p_0001.htm

Received 25.02.2020

Mamedov Z.I., postgraduate student at Department of World History, Methods of Education and Law Samara State Social and Political University

Maksima Gorkogo st., 65, Samara, Russia, 443099

E-mail: mamedov.zaur.1993@gmail.com 